\title{
The Future of Teaching-learning in Africa: The Quest for Ubuntu Justice in Higher Education
}

\author{
Yusef Waghid \\ Faculty of Education, Stellenbosch University, South Africa, 7602 \\ YW@sun.ac.za
}

\begin{abstract}
Much of the pedagogical work with which I have been involved over the last three decades in higher education directly concerns my relations with students and vice a versa. More recently (Waghid, 2019), I have given some thought to my pedagogical relations vis-à-vis the virtue of caring in an attempt to make sense of my encounters with students in higher education. This article reflects a closer look at pedagogical encounters between students and myself (as a university educator). In a way, I firstly reflect on my teaching and learning in a university context by making a connection between what it means to engage in pedagogical encounters through the act of caring. Secondly, I show how pedagogical encounters constituted by care could enhance both teacher and student autonomy, before, thirdly, tackling the notion that caring in pedagogical encounters cannot be remiss of deliberative iterations. Finally, I argue why caring pedagogical encounters are inextricably connected to an enactment of play which, in my view, corroborates the future of teaching.
\end{abstract}

\section{Keywords}

teaching-learning - Ubuntu - justice - higher education - pedagogy

Any talk about the future of teaching invariably concerns uncovering meanings of teaching itself. From the outset, I do not consider teaching as separate from learning. When one teaches, one learns. In other words, through the act of teaching, there is always the opportunity to learn. Likewise, through learning, 
the potential for teaching cannot be dismissed. Consequently, when one learns, one teaches and, when one teaches, the potential of learning is enhanced. For instance, when I teach, I try to make sense of what I know in relation to understandings of students. The point is, introducing students to the idea of an African philosophy of education, firstly, requires that one make sense of the concept, and how meanings of the concept relate to students' understandings of it. When students make sense of the concept in relation to their own understandings of it, they have learnt. In a way, my teaching of the concept 'African philosophy of education' is intertwined with their understanding of it - that is, their learning. Similarly, my teaching of concepts is also informed by what I learn through teaching. By implication, what one teaches is always connected making sense of what one teaches and others learn. Simply put, teaching and learning are always intertwined. Considering such a view of higher pedagogy, I now prefer to talk about teaching-learning instead of just teaching on its own separate from learning or learning independent of teaching. Accordingly, teaching-learning African philosophy of education involves two interrelated processes: initiating students into particular understandings of a concept; and simultaneously, students making sense of a concept. Teaching-learning does not disconnect what one teaches from what someone else - or one for that matter - learns. Next, I examine how teaching-learning in and about African philosophy of education could unfold.

Elsewhere we (Waghid, Waghid \& Waghid, 2018) argue that African philosophy of education is a philosophical activity whereby one identifies and expounds on major human problems on the African continent before examining their implications for higher education. For example, identifying political authoritarianism as a major problem for Africa and justifying why it is a problem would be necessary for doing African philosophy of education. And, when one examines why and how authoritarianism influences education, such as examining pedagogical ways in which it (authoritarianism) curtails autonomous human agency, one would be enabling African philosophy of education. In this way, doing African philosophy of education would be influenced by both a necessary and an enabling condition of human action. Now to identify and justify something as a problem would be to recognise that specific thing, and concomitantly, to construe reasons why that something is what it is. Considering (identifying) authoritarianism as a problem and justifying why it is a problem would constitute the necessary act of doing African philosophy of education. And, when one offers an account of authoritarianism one both identifies and justifies why the problem is what it is. For instance, just naming authoritarianism as a problem is insufficient without also elucidating that it (authoritarianism) constrains human political behaviour and the freedom 
to exercise political and human rights such as what is happening in Egypt today under the authoritarian regime of Fatah al-Sissi. Then, when one offers reasons why authoritarianism would constrain education, such as when university teachers and students are prevented from criticising a government's crackdown on dissident students and teachers, in particular when such students and teachers speak out against a government's incarceration of dissident university students and teachers, one would enable African philosophy of education to manifest. The point I am making, is that doing African philosophy of education is guided by both a necessary and enabling act of philosophical activity. Thus, when one teaches African philosophy of education one articulates one's reasons about what makes the practice necessary and enabling. But then, teaching such a philosophy of education also requires of students to make sense of the influence understandings of African philosophy of education have on education, more specifically higher education. In this way, teaching African philosophy of education is not independent of learning such a discourse. Consequently, in doing African philosophy of education, teacher and students embark on a teaching-learning discourse. In the next section, I examine why teaching-learning in higher education is invariably connected to the notion of caring.

Any pedagogical encounter between teacher and students invariably invokes relational acts of a teacher and those of students. Yet, when a teacher acts, he or she does so in relation to his or her students, otherwise, he or she would not be embarking on teaching-learning. There cannot be teaching-learning without human relationality or as Africans call it, ukama. What makes teaching-learning what it is, is that it is constituted by the act of relationality. However, human relationality implies that those engaged in the relation, act in a particular way. Now considering that teaching-learning constitutes an act of human relationality it cannot be that participants (teachers and students) do so without encouraging or provoking one another towards acts of teaching and learning. And, when teachers and students provoke one another towards teaching-learning they can be considered as creating conditions for one another to act with care. In other words, provoking one another to gain insights into pedagogical matters is a matter of invoking the potentialities of one another to come to understanding - that is, caring is enacted. Caring happens when relational pedagogical acts stimulate both teachers and students to become immersed in teaching-learning. Caring in this sense does not imply that 
teachers and students do acts for one another, but rather that they act relationally with one another as they pedagogically enact their potentialities to teach and learn. By implication, teaching-learning in higher education remains open to relations of care - that is, relations whereby teachers and students care with and not for or about one another. Caring for others would imply that one is doing something for someone else. Such an act of caring would misrecognise the possibility that caring could also be done by the one being cared for or the one who receives care. Likewise, caring about someone would imply that the carer would be unconcerned about the possibility that he or she could be cared for in return. Such acts of caring would be conditional upon the one doing something for someone else before the other perhaps reciprocates. In other words, there is always the possibility of caring for and about someone else for the latter not to replicate caring. Yet, in relational encounters, caring with one another would imply that the participants are always enactors of care. Hence, in pedagogical encounters, the relational act of teaching-learning is invariably underscored by an act of care. That is, teachers and students care with one another to enhance teaching-learning in higher education. Next, I examine how autonomy can be enhanced through the act of caring with others in pedagogical encounters.

Firstly, when teachers and learners act autonomously with care they do not merely act without any consideration with one another as if they perform indiscriminate and unjust acts in relation to one another. In the first place, acting with care requires that teachers and students exercise mutual respect whereby they recognise one another's freedom to exercise their will formation. This means that teachers and students do not just say things to affront one another but rather that they act in ways to provoke one another to act with integrity and honour as they collectively endeavour to make sense of what they engage in, whether it be the calculation of numbers and scores, analyses of poems and literary works, or experimentation with materials and matter. In other words, their pursuits of knowledge construction and reconstruction are bounded by human acts of observation, listening, examining, finding out, and talking back. They do not pursue such human acts without a deep consideration of the other's presence and coming to know. That is, their autonomous acts of examination and experimentation are underscored by a humility to make sense of this or that in relation to one another. Teachers and students would not just justify their insights and findings without considering one another's perspectives on knowledge matters. In this sense, their autonomous acts of getting to know are inextricably bound to their interrelationships with others and others' thoughts and ways of seeing events in the world. By implication, acting autonomously implies that teaching-learning is a pedagogical encounter of relationality-that 
is, of caring with one another on the basis of making judicious decisions on matters of knowledge constituted by mutuality and respect for one another. Acting autonomously does not mean that one acts on one's own. Rather autonomous action means to exercise one's judgments judiciously in relation to other's sense of knowing and being. It is with an exercise of judgment in such a mutually respectful way that one can be said to act autonomously and with care.

Secondly, as has been alluded to, acting autonomously (and with care) invariably involves doing so with others. In another seminal work (Davids \& Waghid, 2019), we examine teaching-learning encounters in relation to deliberative acts of engagement. We argue that teaching-learning is framed by a notion of pedagogic pilgrimage or a spiritual passage of coming to know that exists beyond and outside of us as well as that which is within us (Davids \& Waghid, 2019: xiv). Transcending pedagogical encounters is that action which gives teaching-learning encounters a spiritual orientation such as affirming one's faith and hope in shifting one another 'from the familiar to the strange, from the known to the imagined or from comfort to disruption or disturbance' (Davids \& Waghid, 2019: xv), on the one hand. On the other hand, teachinglearning is also enveloped by that which is within it or, put differently, by the deliberative inclinations that connect our thoughts and pedagogical aspirations to become critical and to struggle against injustices perpetually. We aver that deliberative encounters are endemic to engaged teaching-learning. Without articulations, listening and talking back, teaching-learning cannot be a pedagogical encounter geared towards the cultivation of just human relations. However, deliberative encounters can also constrain teaching-learning in the sense that the possibility is always there for encounters of argumentation and persuasion to exclude those who are less eloquent and argumentative. Consequently, a renewed understanding of deliberative encounters is one where teachers and students remain open to one another's inter-relational experiences without being constrained to act wisely - a matter of not closing itself off within an encounter to one another's expectations. Our argument for an expansive view of deliberative encounters is one that connects with a moral imperative such as for deliberative encounters to become spiritually motivated in addition to their intellectual experiences (Davids \& Waghid, 2019: 13). As articulated elsewhere (Davids \& Waghid, 2019: 21):

[E]mbarking on deliberative encounters for the sake of 'unselfing' and transcending oneself could create the possibility that such encounters would be emotively guided. If the latter happens it seems very unlikely that human prejudice, stereotyping and marginalization of others in 
deliberative encounters would be imminent. The upshot is that deliberative encounters might turn out to be spiritually deepened pilgrimages ... [to] become openings of freedom and justice where teachers and students do not act in ways to subvert one another's contributions. Rather, they are spiritually awakened to encounter one another as persons who not only require respect and acceptance but also a responsiveness that they are worthy of meaning-making who deserve to be treated as equal moral beings.

Now that I have shown how caring in pedagogical encounters can be enhanced through autonomous and deliberative human actions, I turn to a discussion of teaching-learning in relation to an act of play.

\section{Teaching-Learning and Play}

In the previous section, I made an argument in defence of caring within teaching-learning on the basis of autonomous and deliberative pedagogical encounters. Central to an understanding of teaching-learning that recognises respect for persons and, an opening to freedom and justice, is a notion of caring beyond autonomy and deliberations. Already I have intimated that pedagogical encounters should traverse the realm of the sacred by linking such caring encounters to the idea of a spiritual pilgrimage. I now show why Giorgio Agamben's (2007) idea of play offers a way to extend teaching-learning beyond mere autonomous and deliberative encounters - that is, into the future. In his book, Profanations (Agamben, 2007: 76), he explains play as follows:

Children, who play with whatever old thing falls into their hands, make toys out of things that also belong to the sphere of economics, war, law, and other activities that we are used to thinking of as serious. All of a sudden, a car, a firearm, or a legal contract becomes a toy. What is common to these cases and the profanation of the sacred is the passage from a religio that is now felt to be false or oppressive to negligence as vera religio. This, however, does not mean neglect (no kind of attention can compare to that of a child at play) but a new dimension of use, which children and philosophers give to humanity.

My interest is in Agamben's (2007) explication of play in relation to what it means to profane. 'For to profane means not simply to abolish and erase separations but to learn to put them to a new use, to play with them ... in order to 
transform them into pure means' (Agamben, 2007: 87). Three aspects emanate from the afore-mentioned understanding of profanation: firstly, by creating a 'new use' for something implies 'deactivating an old use' of that something and thus rendering the use of it 'inoperative' (Agamben, 2007: 86). For instance, the idea of an African philosophy of education, besides having being considered by many critics as not philosophy because of its reliance on oral narratives, as if human stories have no bearing on philosophical activity, is an example in case. A new use of the practice can be associated with an identification of problems and an examination of the implications of such problems for education in much the same way a child, plays with his or her drinking bottle and discovers that, when he or she hits the bottle against the table, sounds emanate. The bottle soon becomes an instrument of making sounds for the child. The 'new use' of the bottle is that the child stopped using the bottle to drink and hits it against the table to make sounds and by implication, to play through 'pure means' (Agamben, 2007: 88) - referring to that notion which represents a deactivation and rupture from the previous use of the bottle. It is not that the child has temporarily abandoned the previous use of his or her drinking bottle. Rather, he or she has found a new use for it, which can be considered making sense of the bottle in a different and perhaps unexpected way.

Secondly, when someone plays, he or she does so by re-inventing the purpose of his or her toys. A girl child does not always use her pram in exactly the same way for the same purpose. It can also be that a pram is no longer used to carry a doll but also that it be used as storage for other toy pieces. The child learns to put her toy (a pram) to a new use - that is to play with it. When she does so, she not only puts her toy to a new use but also contradicts the initial purpose of the toy (pram), namely to be played with. In other words, the act of contradicting and perhaps abolishing the use of the pram is tantamount to showing dissent with a previous use of the toy. By implication, play opens up the possibility for dissent. Elsewhere, we argue that 'dissent enhances the possibility for educational encounters to be controversial and informative, rather than just collapsing into moments of agreement without rupturing one another's intellectual perspectives' (Davids \& Waghid, 2018: 148). And, considering that play gives rise to an enactment of dissent, the possibility is always there for enhanced teachinglearning in the sense that dissent 'offers the spaces and opportunities for encounters to be more thoughtful and provocative as both teachers and students would be urged by one another's dissenting views to come up with even more plausible perspectives' (Davids \& Waghid, 2018: 149). Put differently, dissent offers a gateway to renewed thinking and understanding so that the possibility is always there to look at things as if they could be otherwise. 
Thirdly, to embark on play is tantamount to a political task of resistance (Agamben, 2007: 77). Such an understanding of play, that is, one that strives to uphold political resistance against acts of despair and societal destruction seems to resonate with an idea of decoloniality that is gaining currency in African higher education today. I now show how decoloniality as an act of profanation offers hope for the future of teaching-learning in African higher education.

\section{$4 \quad$ Cultivating Play through Decoloniality: The Quest for Ubuntu Justice}

Many of the debates in and about higher education transformation on the African continent and, specifically in South Africa, revolve around practices of decolonisation and decoloniality. In this section, I prefer to talk of decoloniality for the reason that decolonisation is directly linked to counteracting and eradicating the outcome of colonisation on the African continent. Undoubtedly, decolonisation has been an important political and moral process of change in the sense that African communities that were impoverished by the imperialist agendas of people from Europe and Britain were dealt a heavy blow by forces of democratisation and political autonomy on the continent. Inasmuch as many African countries had been decolonised from the political control of their colonisers, the effect of colonisation on societal and institutional structures, such as university systems, has been indelible. Following Chinua Achebe's (1989: 85) attempts to redress human and non-human injustices, such as genocide, human trafficking, ethnic conflicts and wars on terror, environmental degradation and deforestation are therefore more in line with decoloniality rather than decolonisation. And, to be concerned with political and moral struggles of those peoples marginalised and excluded on the African continent is tantamount to reimagining a future whereby peoples are re-humanised (Wa Thiong'o, 2012: 10) - a matter of being concerned with the manifestation of decolonial actions. Considering that 'gateways to a new happiness' for African communities are situated in the act of play (Agamben, 2007: 76), decoloniality could be described as a gateway to political resistance and emancipation in the same way play constitutes such 'a new happiness' (Agamben, 2007: 87). The point I am making, is that decoloniality is possible through the cultivation of play. Yet, the cultivation of play - and by implication decoloniality as has been mentioned above - re-humanises people such as when they begin to exert their human freedom and liberation in the 
quest to respond to the predicaments they (humans) encounter in their lives. The injustices, humiliations and struggles they encounter can be more appropriately rebuffed in relation to acts of decoloniality on the grounds that the latter is inextricably connected to cultivating ubuntu justice. Put differently, when decoloniality as an act of play is exercised, the possibility for cultivating ubuntu justice on the African continent is more profound. It is to such a discussion that I now turn.

Like play, decoloniality and ubuntu justice are acts of political resistance. I cannot imagine the future of teaching-learning in higher education on the African continent being remiss of cultivating ubuntu justice for the following reasons. Firstly, like play preserves profane acts of humanity (Agamben, 2007: 71), decoloniality preserves ubuntu justice by freeing and distracting humanity from moral injustices. The post-apartheid South African appeal for human equality, freedom and justice for all is an example of how ubuntu justice disrupts inequality and inhumanity as ubuntu 'is intertwined with the recognition of people's equality and, by implication, their humanity' (Waghid et al., 2018: 41). Put differently, play in the form of cultivating decoloniality is concerned with a kind of political resistance that speaks to counteracting any possibility of poverty, inhumanity and suffering. Secondly, decoloniality also recognises that ubuntu justice could manifest in compassionate justice where Africans enact the virtue of ubuntu in acknowledging the vulnerabilities people on the continent might suffer and doing something about their misery and pain. In other words, showing compassionate justice through the play of decoloniality is at once concerned with African people's vulnerabilities, in particular against exploitation and corruption (Waghid et al., 2018: 44). Thirdly, the play of decoloniality also urges people to enact restorative justice, which 'has the potential to bring opposing ethnic factions to engage with one another for the purpose of building a shared community ... [o]n the basis of reconciliation and forgiveness...' (Waghid et al., 2018: 47). In sum, the play of decoloniality invokes the notion of ubuntu justice that can harness 'moral autonomy, compassionate action and restoration among different ethnic groups and the potential for ensuing conflict might be thwarted' (Waghid et al., 2018: 47).

The argument above is that teaching-learning through the play of decoloniality could make happiness dawn on university teachers and students. In this concluding section, I reflect on Agamben's thoughts on happiness and how 
this could possibly enhance the play of decoloniality. Agamben (2007: 20) posits that happiness does not depend on a state of consciousness but rather, 'on a magic walnut or an "Open sesame"'. In this sense, happiness seems to be connected to an unexpected occurrence. Following Agamben (2007: 20), someone who claims to be happy 'has [therefore] already ceased to be so' on the grounds that happiness cannot be known in advance in one's consciousness. Such a situation in turn, would render happiness a human possession and not something instigated by 'magic' or some unexpected event or situation not given thought of prior to its (happiness) occurrence. Moreover, Agamben (2007: 21) extends happiness to the realm of that which 'we could never dream of deserving'. In other words, happiness remains unimaginable and can be enjoyed only through enchantment.

Finally, 'happiness is reserved only for others (happiness is, precisely, for us) but that it awaits us only at the point where it was not destined for us' (Agamben, 2007: 21). The point about happiness is that it comes as a surprise through 'magic' - that is, 'happiness coincides entirely with our knowing ourselves to be capable of magic' (Agamben, 2007: 21). If teaching-learning is about playing in the quest for happiness then such pedagogical encounters would remain about the unexpected (improbable), unimaginable, and surprise. Such an act of play that is concerned with a teaching-learning encounter does not involve creating relationships but rather, being summoned by one another within an encounter - a matter of being called to happiness. And, to be summoned by a teacher to speak his or her mind, is a matter of students being invited to exercise their equal intelligence and to come into presence (Rancière, 1991). For once, teaching-learning would no longer be associated with an understanding that a teacher transmits knowledge to students. The latter implies that students would be able to think for themselves without always having to be told by teachers to do so. In other words, the authoritative position of a teacher as the one who possesses superior knowledge is at once broken down and his or her position of master explicator is brought into question.

Exercising one's ability to speak is connected to exerting one's equal intelligence (Rancière, 1991). This implies that a teacher should resist speaking alone, but should rather encourage his or her students to come to their own speech a matter of the students exercising their equal ability to speak, and thus giving an account of their reasons. Moreover, limiting one's speech on the basis of not offering explanations all the time would create conditions for students to offer explanations themselves albeit incoherent or underdeveloped. The point about exercising intellectual equality on the part of both teachers and students has to do with them (teachers and students) exercising their equal intelligence 
(Rancière, 1991: 10). Thus, teaching-learning encounters instigated by an exertion of equal intelligence are a matter of teachers and students summoning one another to speak their minds. Moreover, acknowledging that students can think and provide explanations themselves is not just a matter of them exercising their equal intelligence but also a matter of rupturing teachinglearning encounters. By doing so, they provoke one another to come into their own presences and opening up to one another as well as being open to that which is new and unexpected (Rancière, 1991: 13). Only then would both teachers and students be prepared to take risks within teaching-learning encounters on the basis that taking risks has to do with them (teachers and students) in the first place having the freedom to speak, explain and come into their presences - a matter of freeing themselves from domination and control. Put differently, teachers and students, expressing their equal intelligences, rupturing pedagogical relations and taking risks invariably remain inclined towards seeing things anew and with the purpose of doing things for new purposes that is, to play. Such seems to be the future of plausible teaching-learning for African higher education - a situation, in turn, that could contribute towards the eradication of authoritarian practices in the long run.

In sum, I commenced this article with a view that teaching-learning should be subjected to caring relations. Through caring within pedagogical encounters, the possibility is there for play always to be enacted. Then, I made an argument for a play of decoloniality in African higher education to be connected to the cultivation of ubuntu justice. And, if decoloniality were to be aspired towards, ubuntu justice might possibly manifest to give rise to a happiness that instigates teachers and students to exercise their equal intelligences. Such would possibly be the future of higher education in Africa on condition that plays of decoloniality would manifest in unconstrained human actions.

\section{Bionote}

Yusef Waghid is an African philosopher of education and distinguished professor at Stellenbosch University in South Africa. He is the author of the following books: Teaching and learning as a pedagogic pilgrimage: Cultivating faith, hope and imagination (London and New York: Routledge, 2019 with Nuraan Davids); Towards a philosophy of caring in higher education: Pedagogy and nuances of care (New York: Palgrave-MacMillan, 2019); and Rupturing African philosophy of teaching and learning (New York \& London: Palgrave-MacMillan, 2018 with Faiq Waghid and Zayd Waghid). 


\section{References}

Achebe, C. (1989). Hopes and impediments: Selected essays. New York, NY: Anchor Books.

Agamben, G. (2007). Profanations. Translated by J. Fort. London: Zone Books.

Davids, N. \& Waghid, Y. (2018). Tolerance and dissent within education. New York, NY: Palgrave-MacMillan.

Davids, N. \& Waghid, Y. (2019). Teaching and learning as a pedagogic pilgrimage: Cultivating faith, hope and imagination. London: Routledge.

Rancière, J. (1991). The ignorant schoolmaster: Five lessons in intellectual emancipation. Translated by K. Ross. Stanford, CA: Stanford University Press.

Wa Thiong'o, N. (2012). Globalectics: Theory and the politics of knowing. New York, NY: Columbia University Press.

Waghid, Y. (2019). Towards a philosophy of caring in higher education: Pedagogy and nuances of care. New York, NY: Palgrave-MacMillan.

Waghid, Y., Waghid, F. \& Waghid, Z. (2018). Rupturing African philosophy of teaching and learning. New York, NY: Palgrave-MacMillan. 